\title{
Revisiting Shari'ah, democracy and human rights in Nigeria
}

\author{
Authors: \\ Williams O. Mbamalu ${ }^{1}$ \\ Affiliation: \\ ${ }^{1}$ Faculty of Theology, \\ North-West University, \\ Potchefstroom Campus, \\ South Africa \\ Correspondence to: \\ Williams Mbamalu \\ Email: \\ mbamalu_christethics@ \\ hotmail.com \\ Postal address: \\ PO Box 20679, Noordbrug \\ 2522, South Africa \\ Dates: \\ Received: 21 Apr. 2010 \\ Accepted: 03 Sept. 2010 \\ Published: 13 Dec. 2012 \\ How to cite this article: \\ Mbamalu, W.O., 2012, \\ 'Revisiting Shari'ah, \\ democracy and human rights \\ in Nigeria', In die Skriflig/ \\ In Luce Verbi 46(2), Art. \\ \#70, 9 pages. http://dx.doi. \\ org/10.4102/ids.v46i2.70
}

(C) 2012. The Authors.
This article argued that in a pluralistic and complex society such as Nigeria the invocation of Shari'ah (Islamic law) does not augur well for the survival of democracy. The traditional belief of every Muslim is that fundamentalism has been and must continue to be rooted in the concept of theocracy upon which the medieval institution of the Caliphate actually rested. Muslim political leaders challenge the agitation for a secular state in Nigeria as an inspiration by Christian theology based on Western European thought. This article argued that political and social progress in Nigeria is unrealistic without the separation of religion and politics. It was identified in this article that the separation of religion and politics does not go down well with Islamic eschatology and cosmology, because Islam's main theological drive is toward an Islamic world empire. The solution offered in this article was that emphasis should be on ensuring that any legal framework or constitutional arrangement should be one that safeguards the interests of all citizens.

'n Blik op Shari'ah, demokrasie en menseregte in Nigerië. Hierdie artikel argumenteer dat, in 'n pluralistiese en komplekse samelewing soos Nigerië, die aanroeping van Shari'ah (Islamitiese wet) niks goeds voorspel vir die oorlewing van die demokrasie is nie. Die tradisionele geloof van elke Moslem is dat fundamentalisme in die konsep van teokrasie, wat sy oorsprong in die Middeleeuse instelling van die Kalifaat het, gewortel is en so moet bly. Politieke Moslemleiers beskuldig die Christelike teologie (wat op die Wes-Europese gedagte gebaseer is) as die oorsaak van die onrus as gevolg van die poging om 'n sekulêre staat in Nigerië tot stand te bring. In hierdie artikel is ook geargumenteer dat politieke en sosiale vooruitgang in Nigerië nie moontlik is sonder die skeiding van godsdiens en politiek nie. Daar is ook bevind dat die skeiding tussen godsdiens en politiek nie by die Islamitiese eskatologie en kosmologie inpas nie, omdat die Islam se belangrikse teologiese oogmerk ' $n$ Islamitiese wêreldryk is. Die slotsom van die artikel is die beklemtoning van die feit dat enige wetlike raamwerk of grondwetlike samestellings daarop gerig moet wees om die belange van alle burgers te beskerm.

\section{Introduction}

\section{Country overview}

Nigeria is truly the giant of Africa. With a population of over 150 million it is twice the size of Egypt, three times the size of South Africa and 12 times the size of Zambia. In area it is roughly equivalent to France, Italy, Belgium and Holland combined. From Lagos in the south-west to Maiduguri in the north-east is the same distance as between London and Warsaw. The country has over 200 tribes and languages. There are three major tribal groups: the Yoruba in the west, the Ibos in the east and the Hausa-Fulani in the north. The minority tribes and ethnic groups together, however, are more or less equal in number to the 'Big Three' combined. ${ }^{1}$

Before Nigeria became a British colony in the first 60 years of the 20th century, an Islamic revolution took place in Northern Nigeria in 1804. This created a huge caliphate that led to the spread of Islam. By 1842, Christianity was already gaining successful missionary waves in the country and from then on Christianity and Islam became the two dominant religions in Nigeria. The north, east and western part of the country were separate entities under British protection. The name Nigeria was officially adopted in 1897 and by 1914 the British amalgamated the Northern and Southern Protectorates. The famous Richards Constitution written with British colonial oversight took effect in 1946, and established a central legislature and three Regional Houses, namely the Northern, Eastern and Western Houses of Assembly, and later the MidWestern Region was created. This period marked the beginning of various constitutional reforms that led to Nigeria's independence from Britain on 01 October 1960. Nigeria's attainment of

1.This is how John de St. Jorre (1972) opens his story of The Nigerian Civil War. However, the official population of Nigeria is 150 million and there are over 400 languages; the term tribe is considered derogatory. Instead ethnic group(s) is preferred. 
independence came with many concessions to the North, which did not consider itself ready because of its perceived lack of human resources. In the federation, the North was the least exposed to Western education.

In 1966, the first military coup that overthrew the civilian government abruptly ended the First Republic. This eventually led to the Nigerian civil war (1967-1970). At the outset of the civil war on 03 July 1967 and with the declaration of the Republic of Biafra, the administration of General Yakubu Gowon that presided over the war, divided Nigeria into twelve states. Presently, Nigeria exhibits 36 states on her geographical table, excluding the Federal Capital Territory (FCT), Abuja. Between 1967 and 1979, Nigeria was ruled by military dictatorship headed by army generals from the northern part of the country. ${ }^{2}$ In October 1979, the second republic was inaugurated and headed by a Muslim Northerner, Alhaji Shehu Shagari. The government of Alhaji Shehu Shagari was overthrown by another Northern general, Muhammad Bhuhari, in 1983. From then onwards, the generals mainly from the North resumed rule until 1999 when a former army general, Olusegun Obasanjo, a Christian from south-western Nigeria, assumed the reins of power. Coming on the heels of this return to a democratic government, was the issue of Shari' ah (the moral core and religious law of Islam) and its implementation in the 12 Northern States ${ }^{3}$ which triggered a controversy both in Nigeria's Northern States and all over the country and abroad. This article will engage the circumstances surrounding the introduction of Shari'ah in the Northern States, and argues that in a pluralistic society such as Nigeria the invocation of Shari'ah does not augur well for the survival of democracy.

\section{The introduction of Shari'ah in 12 of Nigeria's Northern States}

With the installation of a democratic government in Nigeria in 1999, under the leadership of Olusegun Obasanjo as president, the introduction of Shari'ah in 12 of Nigeria's Northern States has been a subject of much debate and of many controversial changes in Nigeria's laws. Muslims in Nigeria have for many years observed the precepts of Shari'ah. It became a matter of national concern when the then military leader of Nigeria, General Ibrahim Badamasi Babangida, endorsed Nigeria's membership of the so-called Organisation of the Islamic Conference (OIC) in its summit held in Fez (Morocco) in January 1986. This was when it became clear to non-Muslims that Shari'ah or Islamic law in Nigeria and indeed in the Muslim world, is an issue that is inseparable from the declaration of Islam as a faith. In Nigeria for example, the motivation for officially introducing Shari'ah has to do with the perceived conviction of Muslims that Islam has gained strong political grounds and has 'spread rapidly into the coastal areas where it was a stranger

2.General Obasanjo, a Southerner, only assumed power at the death of Genera Murtala Mohammed, a Northerner who was assassinated in 1976. The impression should not be created that all Northerners are Muslims, for General Yakubu Gowon, should rul from 1967-1975 was a Christian. Gen from the North, overthrew the government of Gowon.

3.Nigeria operates a federal system of government and is presently made up of 36 states each ruled by a governor. The constitution allows for a certain degree 36 states each ruled by a governor. The constitution allows for a certain degree
of autonomy for the states in terms of personal laws such as marriage, divorce, inheritance, will and custody of children. before' (Parrinder 1953:1). The power of the majority in any given society must not only be the concern of human rights organisations; it also deserves serious ethical mediation. This is because the historical pattern of Islam shows that when a nation gains a sufficiently large Muslim population, they will begin to agitate for Shari'ah to be implemented. This is the case in Nigeria where Shari' ah has been officially moved from the private precepts of observed law to the public domain as a national law. Recently, and following the introduction of Shari'ah in 12 of Nigeria's Northern States, Nigerians began to express anxiety as the international community raised concerns at the severity of the verdict of Shari'ah, namely flogging, amputation and sentencing to stoning. In response to the harshness of the punishments, which to locals and the international community reflect improper use of Islamic Law, scholars from the University of Jos (Nigeria) and the University of Bayreuth (Germany) devoted themselves to a year-long project under the title 'The Shari'ah Debate and the Shaping of Muslim and Christian Identities in Northern Nigeria'. At one of the conferences and workshops organised by scholars of these universities, An-Na'im (2005), states that:

Shari'ah does indeed ... have a most important future in Islamic societies and communities for its foundational role in the socialization of children, sanctification of social institutions and relationships, and the shaping and development of those foundational values that can be translated into general legislation and public policy through the democratic political process. But it does not have a future as a normative system to be enacted and enforced as such by the state as positive law and public policy. (p. 327)

Non-Muslim Nigerians were able to recognise the significant confusion and suspicion surrounding Shari'ah as an attempt to mark territory within the federation. After all, Nigerian Muslims have in their private domain observed the precepts of Shari'ah prior to its official implementation in the Northern States. Obviously, it appears that the official and effective application of Shari'ah has been deliberately much delayed in experimenting on politics in Nigeria's Northern States until an opportune time. In defence of the recent official implementation of Shari'ah, Ali Ahmed (2005) asserts that:

Debates over the proper role of Shari'ah in the public life of modern Muslim societies are not new, but they are attracting increasing attention since the current religious reawakening the world over. This is more so in the case of Nigeria since the extension of Shari'ah implementation beyond the traditional personal law realm to the public sphere. (p. 358)

This assertion glosses over the Constitution of the Federal Republic of Nigeria (1999) that allows for a restricted application of Shari'ah with regard to personal laws such as marriage, divorce, inheritance, will and custody of children, but not to all and sundry within the federation.

In view of the various debates on issues of Shari'ah in Nigeria's Northern States, this article attempts a slightly detached position that embraces a multidisciplinary ${ }^{4}$ approach in an attempt to look at the issues under survey from a number

4.Shari'ah has to do with human life, which borders on social science, and needs to be studied systematically. However, Shari'ah is not religion only or law only. Religiously grounded moral beliefs affect the socio-political and ethical choices of all, and grounded moral beliefs affect the socio-political and ethical choices of all, and
it impinges on coexistence with others, on constitutionalism and international it impinges on coexistence with others, on constitutionalism and international
relations. These perspectives are reflected in the arguments offered in this article. 
of perspectives. We hope this will complement what is already written regarding the tension between Shari'ah and democracy in Nigeria. To be precise, this article evaluates the application of Shari'ah in the Northern States and problematises its application in relation to human and/ or women's rights issues within the context of Nigeria's nascent democracy. The significance of Shari'ah is placed in perspective in the section that follows.

\section{The significance of Shar'iah to Muslims}

The general perception is that Shari'ah does not have a life of its own outside of the Qur'ân, which is Muslim's sacred scripture as revealed to Prophet Muhammad and the Traditions of the Prophet (Hadith). For example:

[W] hen negotiations began in 1999 between the white minority regime and the African National Congress, a reformist group believed that Muslim personal law, as a component of Shari'ah, was divine and thus not susceptible to change and interpretation, particularly with regard to issues clearly stated in the Qur'an and the Sunnah of the Prophet. (Abdulkader 2005:33)

In other words, the implementation of Shari'ah became synonymous with the acting out and living out of Allâh's divine injunctions in socio-political practice. This is because Islam embraces religion as a State idea, and without the State, religious truth lacks the necessary political instrument to establish and maintain it. And for this reason, the supremacy of the Qur'ân and Shari'ah requires personal aggression and the State instrument to enforce it. Iran is a purely Muslim country and the 'Islamist in Nigeria, especially the North were inspired by the Iranian revolution which funded hardcore members of the Nigeria's Northern Islamist movement' (Kane 2003:94). The message in 1982, which Ayatollah Khamenei sent out to all Muslims reads 'we are going to change the face of the world by Islam, and rule by the Qur'ân ... turn the Mosques into prayer, political, cultural and military bases and prepare the ground for the creation of Islamic governments in all countries'. ${ }^{5}$ Otis (1991:69-129) also fuelled the ambition of Northern Muslims to achieve this religious goal in Nigeria.

Interestingly, the proponents of Shari'ah in Northern Nigeria are drawn from the Malikite School. The Malikite School was founded by Abu Abe Allah Malik b. Anas (715-795 AD). He lived mainly in Arabia (Medina) and was a traditionalist who accepted only precepts based on authenticated traditions. His Kitab al Muwatta is the oldest surviving Muslim law book. The other major collections of Malikite laws are Tahdhib and Bidayat al-Mujtahid. Countries in which Malikite law is practiced are Kuwait, United Arab Emirates, Bahrain, Sudan, Upper Egypt, Libya, Tunisia, Algeria, Morocco, Nigeria and nearly all Western Africa. With the exception of Nigeria, in all the aforementioned countries Muslims are a majority and Islam is the official state religion. Whether or not a country is Islamic does not prevent divergence of opinions regarding the interpretation of Shari'ah. Ayubi (1991) points out divergences amongst Muslim scholars and jurists in this manner:

5.The full text of this message is contained in the work of George Otis, Jr. (1991:69-129)
... the original sources (the Qur'ân and the Hadith) have very little to say on matters of government and the State. The first issue to confront the Muslim community immediately after the death of its formative leader, Prophet Muhammad, was in fact the problem of government, and Muslims had therefore to innovate and to improvise with regard to the form and nature of government. Indeed, the first disagreements that emerged within the Muslim community (and which led to the eventual division into Sunnis, Kharijites, Shi'is and other sects) were concerned with politics. (p. 2)

This fact suggests that for all the claims of unity in Islam, there is enough plurality of voices or interpretations and differences to account for different versions of Shari'ah. It is, therefore, natural that with the introduction of the Shari'ah in 12 of Nigeria's Northern States, different Muslims sects and people of different faiths are bound to react differently to it; it could be by total acceptance, rejection or ambivalence. And this is shown by the fact that agitation for Shari'ah is not made by the Yoruba and the people of Kwara and Kogi States in the south-west and some parts of Bendel State, which was part of the old Mid-Western Region, that have a considerably large Muslim population. Perhaps a question worth examining is: Why, unlike the Yoruba and the people of Kwara, Kogi and Bendel States of Nigeria, are the Northerners all clamouring for Shari'ah or have defiantly and contrary to the 1948 Universal Declaration of Human Rights (UDHR), the International Covenant on Economic, Social and Cultural Rights, and the Covenant on Civil and Political Rights or the Constitution of the Federal Republic of Nigeria (1999), introduced Shari'ah in their states? Another pertinent question is why there is an apparent lack of militancy in the other areas or states of the federation where Muslims have a considerably large population within Nigeria? The answers to these questions have to do with different historical contexts and could be couched in the following terms. It is of note that south-western Nigeria was not subjugated by means of the sword and the spear to accept Islam as a religion. Islam penetrated the south-western region by appealing to the people's spiritual and economic needs, which Islam claimed to offer. As long as the people made their religious, spiritual or economic choices rationally, it was possible to find individuals within any given family or clan expressing different faith beliefs and aspirations.

In addition, the earliest Islamic teachers from Kano and Bornu that worked amongst the southerners did not insist to enforce infractions of taboos that are supposed to prevail in Islam. Even after their conversion to Islam:

[M]any southern Muslims partook freely of alcoholic drinks, and many still do, in spite of later efforts at reform. Women rights were respected or left untouched because purdah was not insisted upon for women. (Parrinder 1953:65)

Moreover, and as a matter of fact fair-minded Muslims admit that most of the Yoruba members of their faith have practically no knowledge of Arabic, apart from a few of the commonest prayers and short suras in that tongue. (ibid.)

Furthermore, many Muslim parents amongst the Yoruba felt obliged to send their children to Christian mission schools to receive a good Western education which would enable them 
to start on a successful career in a highly competitive country such as Nigeria. This lack of Western education in the North was part of a highly felt need not to accede to the West's and East's demand for independent Nigeria. Most importantly is the fact that the south-western people are bound up by tribes and clans whilst the Northerners are bound up by religion. ${ }^{6}$ David Laitin (1986) in his assessment of religion as the marker for politics in the North when compared with the South aptly argues that:

Religion (and not tribe), then, has become the leitmotif for northern politics as ancestral city (and not religion) has become in Yorubaland. Yorubas organise in terms of ancestral city for internal battle and tribe for Nigeria-wide politics; northerners organise in terms of religious brotherhood for internal battle and world religious membership for Nigeria-wide politics. (p. 163)

The root cause of this fostered unity amongst the Muslims of the North finds explanation in the 'exemplary job of Uthman dan Fodio who united the diverse desert peoples under a common version of Islam' (Laitin 1986:163). Thus, according to Soharwardy ${ }^{7}$ (n.d.):

All Muslims know the value and importance of uniting the Muslims around the world. We have read and heard many times the famous verse from Surah Al-i-Imran, 'And hold fast all together the rope which Allah (stretches out for you) and be not divided among yourselves; and remember with gratitude Allah's favour on you; for ye were enemies and He joined your hearts in love so that by His grace ye became brethren; and ye were on the brink of the pit of fire and He saved you from it. Thus doth Allah make His signs clear to you; that ye may be guided' (Verse 013, Al-i-Imran).

Therefore, in Islam, the component of Umma Muhammadiya, ${ }^{8}$ is the core of Islamic political theory, the Islamic community. As a matter of fact, it is for every Muslim in the North the primary basis for political identification and mobilisation for the defence of what is perceived as the foundations of faith, that is, the traditional doctrines of the revealed truth of the Qur'ân. This is a sort of fundamentality that strongly affirms the validity of Shar'iah law and the Islamic state.

Although the above set of answers presupposes human rights and freedom of choice in religion embodied in the Constitution of the Federal Republic of Nigeria (1999) 38.(1), which states that:

Every person shall be entitled to freedom of thought, conscience and religion, including freedom to change his or her religion or belief, and freedom (either alone or in community with others, and in public or in private) to manifest and propagate his or her religion or belief in worship, teaching, practice and observance...

The Northerners are entrenched in a universal Islamic logic that accentuates Shari'ah as the supreme commands and injunctions of Allâh that everyone must obey. It is a radical Islamic view that holds that even non-Muslims must be compelled to abide and respect the principles of Shari'ah

6.Most of the comparison has been between the Yoruba of the South west and the Northerners rather than with the Igbos of the South East, for the Muslim population amongst the latter are rather negligible.

7.Syed Soharwardy, (n.d.), 'Unity of Muslim Ummah?'

8.'Ummah means a people's association on the basis of faith in Allâh and his Messenger, Muhammad, and is considered an indivisible organisation that accepts Shari'ah implicitly and explicitly' (verse 013, Al-i-Imran). wherever Muslims are in the majority or in the position of leadership. Apparently, because Muslims claim Islam as a way of life and the only true religion, ${ }^{9}$ Muslim jurists and religious leaders in Nigeria in their attempts to institutionalise the Qur'ânic message of Islam are using the democratic space within the civilian government to achieve their agenda. This logic is also manifesting itself in the mushrooming of jihadrelated organisations that demand the renewal of obligations to Shari'ah to combat social and economic injustices in any nation where it operates. The problem here is that Shari'ah is then invoked as an exclusive Islamic discourse that does not accommodate non-Muslims as full members of a modern ${ }^{10}$ nation. This runs against the very ethos of the emerging non-sectarian democratic government embodied in the Constitution of the Federal Republic of Nigeria. ${ }^{11}$ For example, the 1999 No. 24 Constitution of the Federal Republic of Nigeria States:

1(1) This Constitution is supreme and its provisions shall have binding force on all authorities and persons throughout the Federal Republic of Nigeria. 1(3) If any other law is inconsistent with the provisions of this constitution, this constitution shall prevail, and that other law shall to the extent of the inconsistency be void (1999:LL 15).

Furthermore, a complicating factor is the eschatological implication of Shari'ah as the path, which, if traversed appropriately, leads to the attainment of true faith, salvation and bliss in this world and the hereafter. This eschatological dimension focuses on the ultimate fate of humankind upon which all future good or bad that will happen to believers subsists. At the end of the age, Allâh will return to earth, but before this happens, there will be a falling away of which Prophet Muhammad was said to have given assurance that there would remain a group of his community (umma) upholding the truth until Allâh's command comes for the world to end. ${ }^{12}$ As a matter of fact, Islamic law divides the world into the abode of Islam and the abode of unbelief, war being the normal state of affairs between the two. ${ }^{13}$ Fockry (1997:164) captures Qutb Sayyid's amplification of this point when he argues that:

... the aim of Islam is to liberate humankind from ignorance and religious unbelief; but since philosophical or theological

9.See Qurân Sûrah 3:19: 'Truly, the religion with Allâh is Islam.' Unfortunately most readers stop at the period without reading further to know what the next line says, 'Those who were given the Scripture (Jews and Christians) did not differ except, out of mutual jealousy, after knowledge had come to them.' All Christian activities are considered as a social injustice and declared anathema by Muslims. Sûrah 8:39 says, 'And fight them until there is no more fitnah (unbelief and polytheism, worshipping others besides Allâh) and the religion (worship) will all be for Allâh Alone (in the whole world).'

10.The term modern according to the Oxford Companion to Politics of the World 'meant no more than current or of recent origin, which favoured the new over the old, denied authority to the past, and approved of irreverence to tradition and the old, denied authority to the past, and approved of irreveren
readiness to innovate, to go where no man dared to go before'.

11.El-Zakzaky, a Northern Islamic activist had led quite a few university students from the North in a demonstration against the State based on the slogan 'Down with the Nigerian Constitution' and 'Islam Only'. In 1980, he led some Muslim groups in the burning of the Nigerian Constitution, which they alleged was anti-Islamic (Kane 2003:96ff). They were heavily funded by the Iranian Embassy in Nigeria.

12.The Qurân contains injunctions of hope to gain paradise for Muslims who are faithful, "Verily, We have warned you of a penalty near, The Day when man will see (the Deeds) which his hands have sent forth, And the unbeliever will say, "Woe
unto me! Would that I were (mere) dust!"' S. Lxxviii.40); s. xvi, 22 'our God is one God: As for those who believe not in the Hereafter, their hearts Refuse to know, God: As for those who
and they Are arrogant'.

13.Sûrah 8:39 says, 'And fight them until there is no more fitnah (unbelief and polytheism, i.e. worshipping others besides Allâh) and the religion (worship) will all be for Allâh Alone (in the whole the world).' 
discourse alone is not enough, Islam calls for jihad, or holy warfare, which aims at removing all the obstacles in the way of the onward march of Islam.

Islam's affirmation of the validity of Shari'ah law and the Islamic state drives towards

\section{establishing:}

[T] heocratic social structures because according to the Muslim faith, every person is born a Muslim and distortions of his or her environment lead a person astray to become a Christian, a Jew, or an unbeliever. To be human means to be a Muslim. (Titus, Smith \& Nolan 1995:369-370)

In the context of general interest in Islam and the Muslim world, it is the duty of Muslims to strive for supremacy until Islam conquers the world by prevailing over all other religions. In this struggle, Nigeria has become a focus of attention. The Holy Qur'ân Sûrah 4:59 supports this position and states inter alia:

Not equal are those Believers who sit (at home) And receive no hurt, And those who strive And fight in the cause of Allâh, ${ }^{14}$ with their goods And their persons. Allâh, had granted A grade higher to those Who strive and fight With their goods and persons Than to those who sit (at home). Unto all (in faith) Hath Allâh, promised good: But those who strive and fight Hath $\mathrm{He}$ distinguished Above those who sit (at home) By a special reward.

Muslims believe that Shari'ah is not something the intelligence of humans can prove wrong; it is to be accepted by humans, because it is based on the will of Allâh. Upon this, the conviction of every Muslim is that Islam is intended to be the religion of all humankind until 'Western civilisation, which by three evils: secularism, nationalism and democracy' (Fockry 1997:164), all of which sanction the opinions and wishes of the majority, even when they are shown to be unjust, are completely eliminated. The trend of this argument calls for a brief review of Shari'ah before and after the British conquest of Nigeria.

\section{A brief review of Shari'ah in Nigeria}

Islam first came to Nigeria through the Trans-Saharan trade between the fifth and seventh century CE, affecting mostly the Hausa people of Nigeria. However, it was the jihad movement of Uthman Dan Fodio that was launched in 1804 that facilitated the institutionalisation of Islam in the Northern part of Nigeria that soon rid Hausa land of anti-Islamic practices. For instance, by 1826, the principal towns of Hausa land such as Kebbi, Gobir, Zamfara, Sokoto, Katsina, Zaria, Nupe, Kano, Bauchi, Uwandu, Adamawa and Ilorin were fully captured by the jihadist movement of Dan Fodio. Subsequently, as Okunola (1993:25) recounts 'the jihad followers of Dan Fodio became the leaders of these principal towns and patterned their administration along Shari'ah lines'.

As time passed on, later generations of leaders became oppressive, cruel and ungodly in their use of power. According to Kumo (1993:13) it was the unshari'a behaviour of these later administrators of the Shari'ah system that led, or at least, contributed to the relegation of Shari'ah to the backwater article. of the judicial system in Northern Nigerian society. For example, by the time the British conquered Nigeria, there was not one emirate throughout the Sokoto Caliphate in Northern Nigeria, where the principles, the methods and the procedures of an Islamic government were applied. As far back as 1903-1958, the British administration in its declared intention to promote human rights and prevent inhuman and cruel treatment of prisoners and accused persons determined which Islamic law principles were wholesome and which were not. With the British as the undisputed rulers of Northern Nigeria, the theoretical basis of the supremacy of Shari'ah ceased to be tenable. In Yorubaland, for example, 'the Lagos Muslim community presented their demand for the establishment of Shari'ah Courts and the application of the Shari'ah to the colonial Governor of Lagos'. However, this demand was refused. This led to Muslims practising Shari'ah in a curtailed fashion that was limited to Muslim personal laws or only 'matters relating to marriage, child-naming and funeral ceremonies' (Okunola 1993:25). The new basis of authority for any action - legislative, executive or judicial - then became the British laws as promulgated by the new rulers. Thus, according to Kumo (1993:8) the application of Shari'ah depended entirely on the laws and the proclamations enacted by the new British rulers.

By the time Nigeria was granted independence in 1960, Shari'ah was already a post-mortem issue in the public political life of the people of Nigeria and in particular the Northern region. However, this turned out to be temporary because Islam clung tenaciously to the notion that there is no distinction between the public and religious spheres and that political power was essential for the promotion of religion. It was quite prepared to fight any authority that muzzled this enterprise. Military rule ensured that Nigeria was governed by a successive battery of Muslim army generals (with the exception of Generals Yakubu Gowon and Olusegun Obasanjo), Shari'ah soon gained prominence. These Muslim army generals at least used the opportunity to both feather and further Islam in Nigeria. By this time, Shari'ah had become fully politicised and, at least in principle, institutionalised and constitutionalised under various regimes of Muslim army generals. It has to be noted that a Muslim president of any country of the world is obliged under the mandate within the principles of territorial rule to promote and further the cause of Islam: 'In territoriality the religion of the ruler is the religion of the country' (Sanneh 1996:131). For this reason, a country's membership of the Organisation of Islamic Conference (OIC) does not require parliamentary process for its endorsement. Thus, in 1976 the military administration under General Murtala Muhammed had set its goal towards inclusion of Shari'ah in the Federal Constitution. This move drew the ire of non-Muslims in Nigeria, but it was too late because prior to this time, a draft constitution had been drawn up and submitted to an intense and pervasive ${ }^{15}$ public debate, which was a mere national voice exercise given the fact that the military regime in practice had already integrated the proposed Federal Shari'ah

15.This was a very vexed debate. For instance, the southern part of the country vowed to remove the Shari'ah provision from the document 'even though the draft vowed to remove the Shari'ah provision from the document 'even though the draft
constitution did not seek to extend the jurisdiction of the Shari'ah Court of Appeal to them' that is, to Southerners (see Yadudu 1993:47-48). 
Court of Appeal into the then Federal Court of Appeal by creating Shari'ah division within it.

As mentioned earlier in this article, Islam by means of jihad entered Nigeria through the North riding on horses; lately Islam has conquered the Constitution of the Federal Republic of Nigeria (1999) riding on military armoured cars. Presently, Shari'ah has become the bone and nerve of politics in Nigeria having been fully institutionalised and positioned to dictate how politics in Nigeria must breathe. It has taken roots downward and is presently used as a pawn in the manipulative game of politics in Nigeria, particularly in the North. However, the concern of many observers such as the Human Rights World Report is that this time around it will be difficult to reverse and upstage the hegemony of the conservative Muslim jurists and religious leaders who insist that Shari'ah must serve as the basis of any legal framework for the proper regulation of Muslim lives in both private and public spheres within the federation. Following the implementation of Shari'ah, the findings of the Nigeria Human Rights Commission established in 1999, assent that 'gross human rights violations have been occurring since the implementation of Islamic Law within the Northern States of the federation' (Constitution of the Federal Republic of Nigeria 1999). With such realisation then, the foremost question in the minds of most Nigerian citizens has become: What are the implications of the blanket application of Shari'ah for the emerging democracy in Nigeria? Is it not a threat to democracy? Or is the demand mature enough to accommodate a pluralistic legal system? To frame the questions differently: Can a religious law co-exist within the ambit of a secular order without mutilating itself or causing constraints on a secular constitution and human conscience? Is it possible to amend the Qur'ân or the Shari'ah? Answers to these questions depend on whether or not the Qur'ân can be contextualised or translated. We will briefly focus on this in the following section.

\section{Translatability of the Qur'ân - theocracy or democracy?}

In the normative sense, from the Muslim perspective the Qur'ân is the collected oracular utterances of the prophet Mohammed and reflects its original copy, the 'Well-Preserved Tablet' kept in heaven. Its contents were communicated to Mohammed through wahy, that is, a direct, divine, immediate and infallible revelatory experience. The prophet as the receptor, recorder and reporter of the divine revelation did everything with the absence of his own thinking or consciousness. This makes the words in the Qur'ân authentically the words of Allâh, the revelation of the divine will in a particular human language, that is, in Arabic. It is such that the book, the prophet and all Muslims belong together. The Hadith brings to the Qur'ân the personality of the prophet, his conduct, sayings, sermons, teachings and exhortations: 'Within all Islamic schools of thought, the Qur'ân is untranslatable' (Sanneh 1989:213). Thus a convert who comes to Islam, automatically adopts Arabic cultural traits, contexts and Arabic scripture whose calligraphy is part and parcel of the divine word. This scripture remains an Arabic Qur'ân in which the supremacy of Arabic is upheld as a guarantee for preserving the purity and truth of the Qur'ân. 'An Arabic Qur'ân, without any crookedness (therein) in order that they may avoid all evil which Allâh has ordered them to avoid, fear Him and keep their duty to Him' (Qur'ân Sûrah 39:28).

Thus, the Qur'ân is oracular in nature, with no narrative matrix in itself within which to locate the events and speech acts of Allâh. As such, the Hadith (the Traditions of the Prophet Muhammad) also forms the essential part of the interpretive context for Islamic law. It is both the Qur'ân and the Hadith which constitute the primary sources of Islamic law. Much later, in addition to this, the consensus of Muslim scholars or ijma and qiyas or analogical reasoning came to constitute other sources of Islamic law. ${ }^{16}$ Whilst this framework of sources exerts high constraints on Qur'ânic relevance, nevertheless, it does provide mechanisms for a creative interpretation of the Qur'ân and Islamic law. However, in a highly homogeneous society such as Northern Nigeria, the culture and the language of the ancient Arabic Muslims is still the determinative factor by which private and public religious life is conducted and ordered. As scripture, the Qur'ân is still locked into specific issues, events and a single human culture with utter disregard for Nigeria's modern democracy, human rights and local contexts. What this means is that under such a framework, the Qur'ân and Shari'ah are supra-democracy, supra-constitution, and supra-human rights. In short, Islam becomes the sole point of reference. What is discernible is that in such an environment it becomes difficult to contextualise Shari'ah or to take up the concerns and conditions of secular, modern or democratic society fully. As a matter of fact, its legal decisions are often promulgated and interpreted by Muslim jurists who apply them to all and sundry without placing them within proper socio-political contexts. ${ }^{17}$ A Shiite representative of the Muslim North, Yakubu Yahaya, said in an open court, although in a different context:

We as Muslims don't recognise the authority of the Federal Government, State Government, Local Government and any form of authority. We do not recognise them as our leaders. We are against them. What is between us and them is enmity, eternal enmity, fight, war, forever until the day they will come to the book of Allah. We as Muslims have our law which is the Koran and Sunna, the traditions of Prophet Muhammed and we execute them under the leadership of Mallam Ibrahim El-ZakZaky. (Albert 1999:83)

Given the prominence of the above-cited religio-political attitude, it will be very difficult for the government of Nigeria

16.The synthesis of qiyas, that is analogical reasoning, and lima, that is a collectivity of decision-making alongside the Qur'ân and Sunna, form the basis of Muslim culture in reality. All in all, the Qur'ân and the Sunna are a unity and remain the sources of legal proceedings. Any perceived contradiction is because of the fact that many schools or sects within Islam, 'worked out different variants "of the fundamentals of dogma" in which they collected in detail their co-ordinated views on various problems of the socio-political history of the Caliphate' (see M. Al-Janabi's 2002:53-57, discussion on 'Islamic Civilization: An Empire of Culture').

17.This is inferred from the fact that 'Member states of the OIC accept the binding authority of its charter, though the power and authority implied in the Qur'ânic verse it invokes might conflict with the sovereignty of national constitutions ... as in Nigeria' (Sanneh 1996:131).

18.Also see Kalu (2002), 'The Religious Dimension of the Legitimacy Crisis, 1993-1998'. 
or its legal framework to dictate the precepts of Shari'ah or call for its contextualisation. This is further compounded by the fact that many Muslims interpret Shari'ah as a closed system that cannot be subjected to human laws. It follows, therefore, that part of the crisis in the application of Shari'ah in Nigeria is not only because of the belief and desire of Muslims to maintain the supremacy of Islamic revelation as a yardstick for governing the society, but also stems from a refusal to rethink Shari'ah in the context of modernity. ${ }^{19}$ This is so, because 'all Muslims are ordained by God to subject themselves to Shari'ah Laws.'20 To paraphrase Abdullah al-Ahsan (1988:19) strict adherence to Islam and Islamic principles and values as a way of life, constitutes the highest protection for Muslims against the dangers of democracy, secularism and nationalism which confront them. Islam is the only path which can lead them to strength, dignity and prosperity and a better future. ${ }^{21}$ In order to avoid the collapsing of the sacred and the secular, Muammar Gaddafi, Libya's late head of state, advocated the dismemberment of the Nigerian Federation into countries along geo-religious lines of the North and South so that the North becomes the main cistern of Islam under a new federation.

\section{Collapsing the sacred and the secular divide?}

Simeon Ilesanmi's (2001) essay, 'Islamic Law and the Politics of Human rights in Nigeria' offers a sober reflection on the theme of this article, which focuses on the tension between Shari'ah and a secular democracy within the context of the modern state in Africa. Rather than point accusing fingers at the irresponsibility of the farin hula, Ilesanmi approaches the issue of the application of Shari'ah in Nigeria by situating it within what he calls 'the perennial issue of determining the proper role of religion in a country's politics'. The refreshing angle in Ilesanmi's perspective is that he strays away from dabbling too much in the normative discussions on the desirability and non-feasibility of applying Shari'ah in Nigeria. In fact he asserts that although Muslims are the most outspoken in debates regarding the public role of religion, they are not alone, '... virtually all Nigeria's religious groups have been actively promoting the reinsertion of religion in the country's politics' (Ilesanmi 2001:2). Ilesanmi then puts forward the view that the Muslim call for Shari'ah, instead of causing a consternation, should be welcomed as providing a window of opportunity for placing on Nigeria's national agenda the issue of the public role of religion. For Ilesanmi, this issue has remained unresolved partly because of the fact

19.This does not mean that modernity resonates very well with the ideals of this paper, for modernity's emphasis is on human mastery, autonomy, power and total rejection of the authority of religion and cultural traditions. Modernity does not find lodging within orthodox Christian religion or Islam for that matter. Modernity by its very definition flourishes within some isms: individualism, empiricism, pragmatism, rationalism, hedonism, liberalism, et cetera. that are contra-religious orthodoxy. What is needed therefore is a creative approach that respects the dignity of human life and the peaceful coexistence of human beings and the environment.

20.The quotation is from a letter the Sudanese ambassador Ali Ahmed Sahloul sent to all the permanent representatives and observers at the U.N. in Geneva on 18 February 1994.

21.See the Declaration of the Third Islamic Summit of 1981 and its interpretation by Abdullah al-Ahsan (1988), OIC: The Organisation of the Islamic Conference: An Introduction to an Islamic Political Institution. that the country for the last decade was preoccupied with 'successive military dictatorship' (Ilesanmi 2001:2), which, of course, favoured the Muslim North.

Taking a cue from Ilesanmi, to make sense of the application of Shari'ah in Nigeria and the resultant tension, is to revisit the question of the nature of the post-colonial state in Africa and the legacy of its constitutional framework and how religion fits within such a configuration. However, this goes beyond the preoccupation with the language of human rights abuse and the normative discourse on the nature of Shari'ah and its significance to Muslims or how it impinges on the rights of others. The problem with the latter tendency is that it leaves matters hanging in suspense and does not help to resolve the systemic impasse between the imperative to either confine religion to the private sphere or allow it to interfere in the public realm, that is, if such a division exists at all. Or is it an imaginary divide?

In grappling with the issues highlighted above, and in dealing with the perennial religious killings in the North Nigerian politics and the legal environment, it is tempting to argue in the manner that Ihsan Yilmaz (2000) has done in an article, 'Is Having a Personal Law a Solution? Towards a Supermodern Law'. To paraphrase Yilmaz's argument (at the risk of distortion), it proceeds along the following lines. The current impasse in Nigeria is rooted in legal positivism which is a pertinent theme of legal modernity (Yilmaz 2000:98-122) and, we should add, the constitutional configuration of the post-colonial Nigerian state. In the context of legal modernity, Yilmaz (2000:101) proceeds, '[l]aw making and application have become a professional area that operates in the name of central national power'. As a matter of fact, this 'central national power tolerates no rivals by means of law to its sovereignty'. The foregoing argument would be worth following up, except that in the Nigerian context we witness the opposite in the form of subversion of the 'central national power' by the Northern States in their demand and subsequent application of Shari'ah. Given such a context, what then, are the implications of Yilmaz's argument for our current discussion?

Simeon Ilesanmi, whom we cited earlier, seems close to a feasible solution when he suggests that the way forward lies in adopting what he refers to as the 'paradigm of a twoway protection and the ideal of comprehensive pluralism in which it is anchored'. Arguably, such a paradigm 'provides a helpful approach by which to negotiate conflicting political and religious interests in Nigeria' (Ilesanmi 2001:24). In his defence then of 'comprehensive pluralism', Ilesanmi contends that it 'militates against the tendency to idolise political victory by using it to subvert the human rights of religious minorities'. This argument seems similar to the sentiment echoed by Mamdani (although in a different context) when he cautions against the 'victor's justice' in favour of a 'survivor's justice'. The latter, namely, a survivor's justice argues Mamdani is more of 'a practical embodiment of empathy than as the settling of a historical score' (Mamdani 
1998:14). Taking Mamdani's argument to its logical conclusion it is tempting to ask whether the Muslim demand for Shari'ah in Northern Nigeria is not premised on settling a historical score. Or is it perhaps a political score?

What can we deduce from the insights put forward by Yilmaz, Ilesanmii and Mamdani so as to take our discussion forward? Perhaps we can start by asserting that the rush to apply Shari'ah obfuscates the various lines between what Bruce Lawrence (2001) has termed the poetics, or performance, of the law with the politics, or implementation of the law' (Mamdani 1998:14). In other words the question is: Is it possible to see Shari'ah as 'performance which has its own ideal or aesthetic form' that 'we can never match in any human society or at any point in present or future practise' (Mamdani 1998:14)? And if so, is not the challenge then for Nigerian Muslims to start by sorting out the ramifications of its ideal or aesthetic form over the rush to implement it? Arguably, it is in the latter context that the insights offered by Yilmaz, Ilesanmi and Mamdani are worth exploring. After all, does the politics of implementation not sacrifice the aesthetics of Shari'ah at the altar of political expediency where Shari'ah is subjected to the charge of gross human rights violations? And can such violations be justified on Islamic or humanitarian grounds? Arguably, when Shari'ah is politicised it retrogresses not only into a penal code that is too eager to amputate limbs and stone sexual offenders to death, but also it retrogresses to what Mamdani (1998) albeit in a different context warns against, namely, the victor's justice. In the context of this article the victors justice manifests itself in punitive laws to offenders. For instance, does the politics or implementation of Shari'ah consider the question of a just social security system, which from classical Islamic jurisprudence is a prerequisite for punishing thefts and related crimes? And as others have charged: what about the crimes of lootocracy or white collar crimes rampantly committed through the stroke of a pen? Or is this the classical case of the law serving the interests of the powerful where the weak and the marginalised are its victims? And if this is the case, can this be called justice? Or is it justice committed in the name of justice? And given these perplexing questions, is there a way forward?

\section{Conclusion}

\section{Which way forward?}

Given the complexity of the questions and issues that we have highlighted, others have argued that the way forward lies in fostering an environment that acknowledges legal pluralism or comprehensive pluralism as the basis of constitutional democracy. Others have vehemently opposed such a perspective arguing that the only feasible solution lies in a strict separation between the secular and sacred realms. In other words, because Shari'ah is strictly a religio-ethical code, it must be confined to the private sphere. Both arguments have merits and it is not our wish to trivialise them. However, in reflecting on a way forward we would like to distance ourselves from the two and seemingly diametrically opposed perspectives. How do we do this?
We would like to conclude with the view that the solution lies not so much in fostering an environment of legal pluralism even if there was a general agreement on its feasibility. Our caution is based on the realisation that nothing stops such a legal framework (legal pluralism) from violating basic human rights. After all, like legal modernity legal pluralism is also capable of being 'repressive to women and children' or the under classes, under the excuse that the State is not always of factual situations in the legal sphere. ${ }^{22}$ However, strict separation is equally problematic. It simplifies the complexity of the public role of religion and entrenches what Ilesanmi (2001:2) aptly calls earlier, 'myths about its inherently private and otherworldly nature'. The question then is: How do we move forward and is there a third way or perspective?

In responding to the above question, it seems that rather than an occupation with labels or particular forms of legal systems, the emphasis should be on ensuring that any legal framework or constitutional arrangement is one that safeguards the interests of all citizens. This view not only appreciates the limits of law, it also seeks to define the place of a religion in a modern state. ${ }^{23}$ Thus, the challenge for Muslims in Nigeria's Northern States is to realise that as there is no conceptual clarity on the social ideal to which Shari'ah aspires in relation to a social reality, Shari'ah itself will not be free of a compassionate and sensitive legal system. After all, as much as Shari'ah is a reflection or expression of divine commands, it is also based on social and human engineering. Thus all Muslims hold as infallible the documents of the Companions of the Prophet (Şahābah) or their immediate Successors (Tābi' $\bar{u} n$ ), and the authority of those early scholars, confirmed by the consensus $(i j m \bar{a}) .{ }^{24}$

It is with regret that we say that the former president of Nigeria, General Olusegun Obasanjo's pronouncement that Islamic Shari'ah in Northern Nigeria would melt into the desert sand, is a glaring presidential ignorance of the true nature of Islam's eschatology and cosmology. It is a defiant statement spoken into the fertile womb of Islamic reformation in Nigeria where there are increasingly more Islamic television and radio programmes; where many new mosques are being built every year; where top quality Islamic books and magazines are heavily subsidised and sold cheaply; where highly trained and paid fundamentalists are all out to change existing laws wherever possible until they correspond to Islamic Shari'ah. Muslims who interpret the Qur'ân in the context of its own history and forms of thought and apply relevant, if not, almost all Qur'ânic insights to contemporary issues know that Northern Nigeria will no longer be free to other fellow Nigerians when Shari'ah is fully implemented. Democracy cannot function where Shari'ah exists, because

22.In addition to critiques on Legal Modernity or Legal Positivism, other more elaborate debates on the regressive nature of law are best captured in works dealing with Women and Law or Feminist Critiques of Law in general. See for instance, Weisberg (1993).

23.For a more detailed discussion on the limits of law see Touri (2000).

24.Majid Fackry (1997) has discussed this under the progress of anti-rationalism and the onset of decline. 
under Shari'ah people must obey the commandments of the Qur'ân and the Hadith. It is a theocratic system which does not guarantee to people the freedom to exercise democratic choice in accordance with their religious or other beliefs. Islam controls money, business, radio and television, politics, as well as family and school, as tools for its propagation. It is not a democratic system in which established rules of law and human rights are emphasised for the good of all.

\section{Acknowledgements Competing interests}

The author declares that he has no financial or personal relationship(s) which may have inappropriately influenced him in writing this article.

\section{References}

Abdulkader, T., 2005, 'The Demand for 'Shari'ah in African Democratisation Process: Pitfalls or Opportunities?', in P. Ostien, J.M. Nasir \& F. Kogelman (eds.), Comparative perspectives on Shari'ah in Nigeria, pp. 27-57, Spectrum Books, Ibadan.

Abdullah, A.A., 1988, The Organization of the Islamic Conference: An Introduction to an Islamic Political Institution, International Institute of Islamic Thought, Herndon.

Ahmed A., 2005, 'Commentary', in P. Ostien, J.M. Nasir \& F. Kogelman (eds.), Comparative perspectives on Shar'ah in Nigeria, pp. 358-360, Spectrum Books, Ibadan.

Al-Janabi, M., 2002, 'Islamic civilization: An empire of culture', in K. Nur \& P. Yuriy (eds.), Values in Islamic culture and the experience of history, pp. 49-75, The Council for Research in Values and Philosophy, Washington.

Ali, A.Y., 1946, The Glorious Qur'an, transl. and commentary, Islamic Propagation Centre International, Durban.

Albert, I.O., 1999, 'Sociocultural politics of ethnic and religious conflicts', in E.E. Uwazie, I.O. Albert \& G.N. Uzoigwe (eds.), Inter-Ethnic and religious conflict resolution in Nigeria, pp. 69-88, Lexington Books, Lanham.

An-Na'im, A.A., 2005, 'The Future of Shari'ah and the Debate in Northern Nigeria', in P. Ostien, J.M. Nasir \& F. Kogelman (eds.), Comparative perspectives on Shar'ah in Nigeria, pp. 327-357, Spectrum Books, Ibadan.

Ayubi, N., 1991, Political Islam: Religion and politics in the Arab world, Routledge New York.
Constitution of the Federal Republic of Nigeria, 1999, Nigeria Human Rights Commision, Government Press, Abuja.

De St. Jorre, J., 1972, The Nigerian Civil War, Houghton Mifflin Company, Boston.

Fackry, M., 1997, Islamic philosophy: A beginner's guide, Oneworld Publication, Oxford.'

Ilesanmi, S., 2001, 'Islamic Law and the Politics of Human Rights in Nigeria', Second Symposium of the Islamic Law in Africa Project, Senegal, Dakar, 29 June - 01 July, n.p.

Kalu, O.U., 2002, 'The Religious Dimension of the Legitimacy Crisis, 1993-1998', in F. Toyin (ed.), Nigeria in the Twentieth Century, pp. 667-685, Carolina Academic Press, Durham.

Kane, O., 2003, Muslim modernity in postcolonial Nigeria: A study of the society for the removal of innovation and reinstatement of tradition, Brill, Boston.

Kumo, S., 1993, 'Shar'ia Under Colonialism: Northern Nigeria', in A. Nura, A. Adamu, Y. Awwal, M. Rashid \& S. Haruna (eds.), Islam in Africa: Proceedings of the Islam in Africa Conference, pp. 1-22, Spectrum Books, Kaduna.

Laitin, D.D., 1986, Hegemony and culture: Politics and religious change among the Yoruba, University of Chicago Press, Chicago.

Lawrence, B., 2001, 'Islamic Law in Africa Conference: Dakar 2001', in Annual Review of Islam in South Africa, vol. 4, pp. 61-63, University of Cape Town, Cape Town.

Mamdani, M., 1998, 'When does a settler become a native? Reflections of the colonial roots of citizenship in Equatorial Guinea and South Africa', Inaugural Lecture, University of Cape Town, South Africa, 13 May.

Okunola, M., 1993, 'The Relevance of Shar'ia to Nigeria', in N. Alkali, A. Adamu, A. Yadudu, R. Motem \& H. Salihi (eds.), Islam in Africa: Proceedings of the Islam in Africa Conference, pp. 23-35, Spectrum Books, Kaduna.

Otis, G. Jr., 1991, The last of the giants: Lifting the veil on Islam and the end times, Chosen Books, Tarrytown, New York.

Parrinder, G., 1953, Religion in an African city, Oxford Press, London.

Sanneh, L., 1989, Translating the message: The missionary impact on culture, Orbis Books, Maryknoll.

Sanneh, L., 1996, Piety \& power: Muslims and Christians in West Africa, Orbis Books, Maryknoll.

Soharwardy, S., n.d., 'Unity of Muslim Ummah?', in Islamic Supreme Council of Canada, viewed 26 October 2012, from http://www.islamicsupremecouncil.com/ unity.htm

Titus, H., Smith, M.S. \& Nolan, R.T., 1995, Living Issues in Philosophy, Wadsworth Publishing, Boston.

Touri, K., 2000, Critical Legal Positivism, Ashgate, Aldershot.

Weisberg, K.D., 1993, Feminist legal theory: Foundations, Temple University Press, Philadelphia.

Yadudu, A., 1993, 'Shar'ia under colonialism: Northern Nigeria', in N. Alkali, A. Adamu, A. Yadudu, R. Motem \& H. Salihi (eds.), Islam in Africa: Proceedings of the Islam in Africa Conference, pp. 42-59, Spectrum Books, Kaduna.

Yilmaz I., 2000, 'Is having a personal law a solution?', Journal of Is/amic Studies 20, 98-122. 